\title{
ENERGY DISCIPLINE KNOWLEDGE CONTROL SYSTEM
}

\section{Oliinyk Yu. S.}

\section{INTRODUCTION}

The problem of technical education is actually now. The engineering education is the base for future development of the economy and social area in Ukraine. The extent of development the technique and technology depend on the level of the qualification the future engineering. Also, it depends on the state of technical and economic potential country and the place of Ukraine in the international market distribution of labor.

Now the time of the solution of the problem is coming. There are:

- Reorientation the industry in the innovative way of development, which is based on the intellectual recourses;

- Improving the living standards;

- Increasing the gross products;

The one of the biggest roles in the solution this task belongs the energetics and engineering staff.

In this modern conditions the necessity of the preparing engineering staff is increasing. As well, the new engineering specialty is started, the engineering and technical department in the university is developing, vocational engineering education is becoming more significant. It's due to objective increase of requirements to the level of the professional knowledge and skills of the specialty in the energy industry.

In the most modern pedagogical works pay attention the problem of the increasing the quality of education in general and the quality the vocational education particular. The country's laws of modernization and developing the education define the amount of quantity the innovation the higher school. The one of them is move to the government standards of higher education. The most important component is the control methods the quality of education. The increasing of the effectiveness and quality the process of education directly depends on the testing and grading the results of the students' academic performance.

The many pedagogical works like V. Avanesov, Yu. Babanskij, V. Bespalko, I. Bulah, V. Zvonnikov, Norman E. Gronlund, V. Petrenko, L. Romanishina, N. Samilkina, M. Chelishkova dedicated the solution problem of the testing of knowledge and skills. In these works, the problems of the testing organization and methodological aspects are developed enough full. It influences on the testing results, test design principles and the various methodologies the test development, the problems of the ensuring reliability 
and validity. According to the demand of the government standards of higher education the theoretical basis of testing students' knowledge and skills were developed enough full.

In this article we consider the system of testing the different kind using educational material of power energy discipline. One of the main disciplines in the process of preparing the future electrician is the discipline "Electromagnetic transition processes". The researchers like A. Vyenikov, V. Vinoslavskij, S. Ulyanov developed quite a lot of methodologies of education students for discipline "Electromagnetic transition processes". After the process of analyses this methodology the conclusion is the system of testing knowledge are characterized not enough realization the diagnostic and training functions.

It's due to the availability contradiction between the necessity assurance the effective the diagnostic and training functions of system testing and low of development the theoretical and practical aspects of realization. The availability this contradiction due to necessity the research the problem of increasing quality the education the future electrical engineering for the discipline "Electromagnetic transition processes" and the test methodology on its base.

\section{The analyses of the methodology of education and the testing of knowledge the future electric engineer}

The main task in the government standards of higher education is the testing of knowledge and skills. The term "testing" means "trial for identifying the characteristic object, which use in the connection with the particular methodology measuring and evaluating the results" 1 .

For identifying of level learning the knowledge on every level uses the testing. It is the special control task of founding of learning of activity particular level with the connecting of particular systems of measure and value of quality of learning. The test is the set of testing tasks and standard (the full and right method the execution of particular activities: $\mathrm{T}$ (test) $=\mathrm{T}($ task $)+\mathrm{S}(\text { standard })^{2}$.

As a rule, the system of knowledge of the technical discipline is the hierarchical system of concept and the logical relationship between each other. While the testing needs to realize the next main function for the likes of teaching, forming, diagnostic and total function. The defining function is realized like "entrance control", which have to use for meaning the level of basic knowledge needs for future successful learning the education material.

The forming function has a learning character and lies in identifying the learning elements, which has a not enough level of formation and has a negative influence on the further learning of teaching material. If the most of students show the low level of the learning education materials the process of his repeating and hardening the educational material will have a learning

\footnotetext{
${ }^{1}$ Беспалько В.П. Слагаемые педагогической технологии. Москва, 1989. 192 с., р. 58.

2 Там само.
} 
character when is carried out the detailing of learning material. If the most of students have a high level of learning materials will be individual consulted for students who has a low level. While the teaching effect of testing is realized.

The diagnostic purpose is founding the reason of the low level the learning education material. This kind of test needs to use with the forming tasks together. If the level knowledge and skills stayed the same after using the process of forming tasks we must use diagnostic tasks. These tests must have the special detailed testing tasks which correspond the content of educational material which left undeveloped. The tests for total function is designed for objective evaluates the results learning materials. This kind of tests checks the quality and fulling learning the educational material which is needed for future success learning discipline. According to the requirements of government standards of higher education the testing technic discipline must realize like the concept (general concept, particular concept) concepts and logical relations between each other ${ }^{3}$.

The government standards of higher education define the next levels of forming these concepts like the orientation level, conceptual-analytical level and productive-synthetic level ${ }^{4}$.

The textbook or teaching manual display the main elements of methodological systems. Also, the purpose and content presented in the textbook or teaching manual full enough, but methods, techniques and forms partially. According to these can be considered that the textbook or teaching manual have the essential information about the methodology or methodical system. It's allowed to use equal concept like "methodology" or "methodical system" during to process of analyses the textbook or teaching manual. The main disadvantage of the testing methodology is the control the knowledge, which were given, has a fragmentary character and doesn't objective. Because there is not full, meaningful and didactic pliancy of the system of tests.

As mentioned, according to the government standards of higher education there are the next levels of learning the materials:

- the orientation level;

- the conceptual-analytical level;

- the productive-synthetic level;

The author of the notion "level of assimilation" the knowledge like "ability to deal with the different tasks" V. Bespalko characterizes in his work such levels ${ }^{5}$ :

- "If the task has a purpose, situation and action of solution and the pupil have to conclude about compliance all three components in the task's structure, it is the action like recognizing", that is the orientation level ("with

${ }^{3}$ Беспалько В.П. Слагаемые педагогической технологии. Москва, 1989. 192 с, p. 58.

4 Ярощук Л. Основи педагогічних вимірювань та моніторингу якості освіти : навчальний посібник. Луцьк. 2010. 308 с., р. 41.

${ }^{5}$ Беспалько В.П. Слагаемые педагогической технологии. Москва, 1989. 192 с., p. 55. 
a clue"). The kind of testing tasks by which they are tested are the testing tasks of recognition, distinction and classification ${ }^{6}$.

- The second level's tests must identify pupil's skills reproduce the information without a clue, use the memory for a solution the typical tasks: "If the task has a purpose and situation, the pupil must use the action which was learnt early for solution, these are the algorithmic reproductive action", that is the task "without a clue"7;

- The third level is described as follows: "If the task has a purpose, but is unclear situation where the purpose will be met and pupil must add the situation and uses the action, which was learnt early, for solution these untypical tasks, this is the productive action heuristic type". In general, the productive-synthetic level is controlled by the standard task which has the particular algorithm for solution ${ }^{8}$.

- The fourth level learning materials V. Bespalko describes like this: "If the task has a general purpose action, the situation and action, which help to achieve the objective, must be found, this is the productive action creative type. As a result, the objective new indicative framework for action is created. In the process of action is defined the new information". The learning materials on the productive-synthetic level is done through the untypical task, algorithm these task's is uncertain and is formed by student in the process of solution ${ }^{9}$.

In the process of analyses, according to the government standards of higher education and V. Bespalko's theory the characteristic of learning material levels matches with learning material levels:

In the process of analyses, according to the government standards of higher education and V. Bespalko's theory the characteristic of learning material levels matches with learning material levels:

The matching with learning material level ${ }^{10}$

Table 1

\begin{tabular}{|c|c|}
\hline \multicolumn{2}{|c|}{ Levels of assimilation } \\
\hline $\begin{array}{c}\text { According to the government } \\
\text { standards of higher education }\end{array}$ & According to V. Bespalko's theory \\
\hline OO - the orientation level & $\begin{array}{c}\text { I level "with a clue" }\left(\alpha_{2}\right) \\
\text { II level "without clue" }\left(\alpha_{22}\right)\end{array}$ \\
\hline CA - the conceptual-analytical level & III level $\left(\alpha_{222}\right)$ \\
\hline$\Pi S$ - the productive-synthetic level & IV level $\left(\alpha_{2 v}\right)$ \\
\hline
\end{tabular}

${ }^{6}$ Беспалько В.П. Слагаемые педагогической технологии. Москва, 1989. 192 с, р. 55.

7 Там само.

${ }^{8}$ Беспалько В.П. Слагаемые педагогической технологии. Москва, 1989. 192 с, р. 55.

${ }^{9}$ Беспалько В.П. Слагаемые педагогической технологии. Москва, 1989. 192 с, p. 56.

${ }^{10}$ Беспалько В.П. Слагаемые педагогической технологии. Москва, 1989. 192 с, р. 55-56. 
The testing's theory is considered in the work of author like I. Bulah ${ }^{11}$, L. Yaroshchuk ${ }^{12}$, N. Samylkina ${ }^{13}$.

Open-type tests are the add-on tests and the tests of free presentation of educational material. They have not the right check of the answers in the task's text and distractors. Distractor means the check of the answers in the tasks with choosing which are not the right but near to the right solution.

Add-on tests are characterized the autonomy of the student's answers a test question. The answer has a limiting character which provides the teacher an opportunity to evaluate clearly. As a rule, these kind of task's instruction sounds like "Write the missing word (formula, number)". The one missing word must comply with the one word ${ }^{14}$.

The tests of free statement unlike to add-on tests don't have answer's limitations. These kind of task has an instruction like "Finish the sentence (definition, theorem, rule, algorithm)". The student must write the word, phrase, sentence or same phrases their way up.

The closed-type tests are the tests of alternative replies, multiple choice, matching, sequencing. These kind of tests is determined by choice the one or few right variant of the answer. That is consist to the right answers and distractors. The alternative response test is the tasks which are characterized the particular options of the variant answer's - "right-wrong". The each of the test tasks has only two variants of the answer, one of them is the right. The test task must formulate in the form of approval with which the student must agree or disagree ${ }^{15}$.

The task of multiple choice is the main difference about in these kind of task - availability the several options of the answer, where including the right answers can be one or few.

The task of sequencing is the type of task sequencing, but significant difference is the feature presence with which must be feature presence from these test elements'. For these kind of test is characterized the low probability guessing the right answer.

The sequencing task is a variety of match task, but has a significant difference which consists in some significant. This sign is a main reason for sequencing task from the element data tasks test. This kind of task is characterized the low probability guessing the right answer. Creative the test

${ }^{11}$ Булах I.Є., Мруга М.Р. Створюємо якісний тест : навчальний посібник. Київ, 2006. 160 c., p. 9.

12 Ярощук Л. Основи педагогічних вимірювань та моніторингу якості освіти : навчальний посібник. Луцьк. 2010. 308 с., p. 39.

${ }^{13}$ Самылкина Н.Н. Современные средства оценивания результатов обучения. Москва, 2007. 172 с., р. 27.

${ }^{14}$ Самылкина Н.Н. Современные средства оценивания результатов обучения. Москва, 2007. 172 с., р. 44.

${ }^{15}$ Самылкина Н.Н. Современные средства оценивания результатов обучения. Москва, 2007. 172 с., р. 39. 
task needs for choosing that kind of task, which are mentioned above and will be considered existing levels of training material according to the government standards of higher education and fit into a classification according to V. Bespalko's theory.

The orientation level is presented by recognition, distinction and classification tasks. Recognizing test is characterized of availability some approval or question of the type which the student gives the answer "yes" or "no". So creating that type of test needs to using tasks of alternative replies ${ }^{16}$.

Distinction test is characterized of availability some answer variants, the right answer must be specified in the list of variants. Creating this type of task must use the task of multiple choice ${ }^{17}$.

The last type of the orientation level task is the classification task. When the student answers to that type of test, should be identified the list of phenomena or elements, which are characterized and united the same particular indication.

So creating the orientation level task is using of close type task which have an advantages compare to open type of task like the objectivity of the assessment, speed of task, minimum spending of time, have the opportunity to cover the most quantity of educational material, a small chance of guessing the right answers.

As state above the conceptual-analytical level and the productivesynthetic level of learning materials are represented by standard and nonstandard tasks consequently. So using the open type of task will be useful on the checking of learning materials on the designated levels.

Assigning a training element to a group and the necessary level identification gives the opportunity to find the optimal form of tasks according to the principal of the pedagogical dimensions for every educational element. So as stated above the fit between the learning level according to the government standards of higher education and the type of the task is shown in the table 2.

Table 2

Conformity with existing type of task and learning levels

\begin{tabular}{|c|c|c|}
\hline Number & Learning level & Existing type of task \\
\hline \multirow{4}{*}{1} & the orientation level & Close type task (task alternative choice) \\
\cline { 2 - 3 } & recognizing task & Close type task (task multiple choice) \\
\cline { 2 - 3 } & distinction task & $\begin{array}{c}\text { Close type task (task for conformity } \\
\text { assessment or task to sequencing) }\end{array}$ \\
\cline { 2 - 3 } & classification task & Open type task \\
\hline 2 & the conceptual-analytical level & Open type task \\
\hline 3 & the productive-synthetic level & \\
\hline
\end{tabular}

${ }^{16}$ Беспалько В.П. Слагаемые педагогической технологии. Москва, 1989. 192 с, p. 61.

17 Ярощук Л. Основи педагогічних вимірювань та моніторингу якості освіти : навчальний посібник. Луцьк. 2010. 308 с., p. 88. 
The main instrument of realization the learning levels testing system for discipline "Electromagnetic transition processes" is the computer program which must have specific requirements and realized the learning level testing system according to the government standards of higher education.

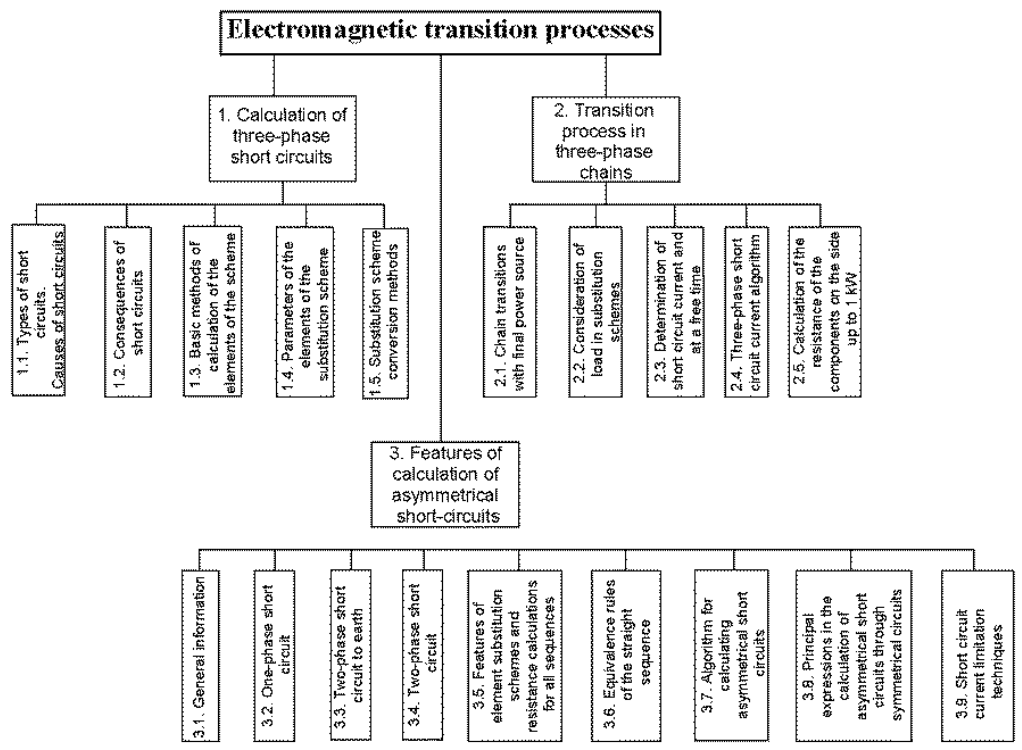

Fig. 1. Fragment of the knowledge system in the discipline "Electromagnetic transition processes" 18

Considering the structural and logical scheme of discipline, we mentioned that the elements of upper levels (for instance, 1.1. Transition processes in power supply systems) connect with elements of low levels (1.1.1. The kind of transition processes. The definition of a short circuit; 1.1.2. Kind of short circuit; 1.1.3. The reasons for appear of short circuit). It's meant that the elements of upper level - the general notions, the elements of low levels - the particular notions ${ }^{19}$.

As was mentioned earlier about the necessary the testing as educational elements as a logical attitude between each other, the testing can do beginning of general notion (deductive form) and can do beginning to particular notion (inductive type).

18 Хоменко В.Г., Олійник Ю.С. Система тестування 3 дисципліни «Електромагнітні перехідні процеси». Харків, 2010. 104 с., р. 11.

19 Хоменко В.Г., Олійник Ю.С. Система тестування 3 дисципліни «Електромагнітні перехідні процеси». Харків, 2010. 104 с., р. 14. 
The induction type is the giving part of the conclusion which is based on the knowledge the several of general provisions.

The induction form of test identifies the same notion or features in the lot of objective the particular kind and can make a conclusion on the presence of these notions, the features all objects which belong to this class.

The induction type of testing is characterized the possibility of checking the student's knowledge beginning of the lowest level, also is characterized by possibility the accurate diagnosis of knowledge which is being given. When checking the knowledge of the unit or topic these kind of tests is inappropriate because the amount spending of time is needed for checking knowledge at every stage. Describing the deductive form of the test, it's necessary to mention the next. The deductive form is the giving of general conclusion on based the particular provisions. Another way the deduction form of test mentions the analyses of the term from the general judgment to particular conclusion.

The semantical analyses allow to highlight the three components which belonging to baseline data: the general notion, the particular notion and the logical attitude, and also, the purpose of testing task like a determination of the existence of this attitude.

\section{The models of different test's kind}

As we mentioned above, in the most cases the logical attitude between the test's elements might be "numerous-element", "reason-consequence", "integer-part". These signs allow to make the conclusion about the possibility the future test's differentiation on the classification V.P. Bespalko.

So, making a conclusion, the model of differential recognition test the inductive form is like this:

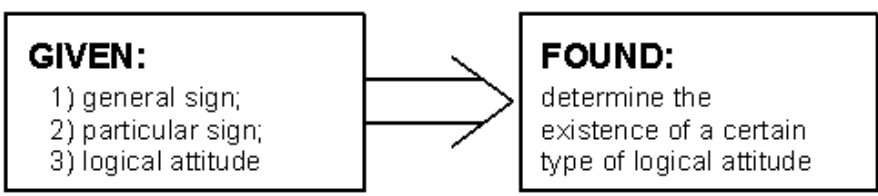

Fig. 2. The model of differential recognition tests the orientation level the deductive form ${ }^{20}$

The model of differential recognition test the deductive form could be the next:

${ }^{20}$ Лазарєв М.І., Олійник Ю.С., Хоменко В.Г. Теоретичні та методичні засади тестування знань 3 електромагнітних перехідних процесів : монографія. Харків. 2012. 176 c., p. 44. 


\section{GIVEN: \\ 1) particular sign; \\ 2) general sign; \\ 3) logical attitude \\ FOUND: \\ determine the \\ existence of a certain \\ type of logical attitude}

Fig. 3. The model of differential recognition tests the orientation level the inductive form ${ }^{21}$

On these based designed the test's model for the recognition the induction and deduction forms:

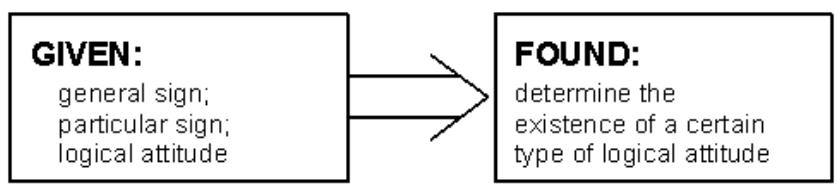

Fig. 4. The model of differential recognition tests the orientation level ${ }^{22}$

Let's consider the particular example of differential recognition test the deductive form with kind of attitude between elements "numerous-element": "Belong or not transition processes to processes, which are connected to switching on or off electric consumers?". In this case the general notion "transition processes", the particular sign - "switching on or off electric consumers". These sign is the part of notion "transition processes". So, these two educational elements are connected to each other by the logical attitude "numerous-element".

Let's consider the particular example of differential recognition test the induction form with kind of attitude between elements "plurality-element": "Belong or not the process of unsynchronized switching on the synchronized machine to transition processes?". These example has the general notion "transition processes", the particular notion - "switching on of the synchronized machine". This test is built the next: firstly, we have a particular notion, after that - the general notion. The sign "switching on the synchronized machine" is the part of notion "transition processes". So, these

21 Лазарєв М.І., Олійник Ю.С., Хоменко В.Г. Теоретичні та методичні засади тестування знань 3 електромагнітних перехідних процесів: монографія. Харків. 2012. 176 c., p. 44.

${ }^{22}$ Олійник Ю.С. Методика тестування знань зі електромагнітних перехідних процесів у майбутніх інженерів-електроенергетиків : автореф. дис. ... канд. пед. Наук : 13.00.02. Харків. 2011. 20 с., р. 7. 
two educational elements are connected to each other by the logical attitude "numerous-element"23.

Let's consider the kind of logical attitude "reason-consequence" by these connects the general and the particular notion in the differential recognition test the induction and deduction forms.

Let's consider the particular differential recognition test the deduction form with logical attitude between each other "reason-consequence": "If the three-phase short circuit appears the all system of current and voltage all phases will be in the same conditions." The general notion, which is on the first place in the question, is the reason - it's "three-phase short circuit", the particular notion, which is the consequence - it's "the same conditional of the system of current and voltage of all phases". This attitude between them - "reason-consequence".

Let's consider the particular differential recognition test the induction form with logical attitude between each other "reason-consequence": "If the electrical equipment insulation is breaking it is the one of the most reasons to appear the short circuit in the network". The particular notion or the reason - "breaking the insulation of electrical equipment", the general notion and the sequence - "the appearing of the short circuit". This attitude between them - "reason-consequence".

Let's consider the particular differential recognition test the induction form with logical attitude between each other "integer-part" by that connect the general and particular notions in the differential recognition test the induction and deduction forms.

The differential recognition test the deduction form with logical attitude between each other "integer-part": "Is there a logical attitude between signs “ $X_{T *}=\frac{U_{K}, \%}{100} \cdot \frac{S_{\sigma}}{S_{\mathrm{H}}}$ " and sign “ $\frac{U_{K}, \%,}{100}$ ?". The general notion, integer - formula " $X_{T *}=\frac{U_{K}, \%}{100} \cdot \frac{S_{\sigma}}{S_{\mathrm{H}}}$ ", the particular notion, the part of whole $-\frac{U_{K}, \%}{100}$ ". The logic attitude between elements - "integer-part".

The next kind of differential tests the first level is the test on the distinction. As V.P. Bespalko mentioned, the characteristic features of tests on the distinction is the existence of a general notion and plurality specific notions.

The participants of test on the distinction will be the one of a general sign and the plurality of the particular signs. Also, between these signs the test on the distinction are checking the existence of a certain kind of logical attitude - "numerous-element", "reason-consequence", "integer-part".

The purpose of the test on the distinction is in identifying from the list of those the particular notions, which refer to the general appropriate notion.

23 Хоменко В.Г., Олійник Ю.С. Система тестування 3 дисципліни «Електромагнітні перехідні процеси». Харків, 2010. 104 с., р. 16. 
For tests on the distinction analogous to the tests is characteristic by the differentiation and the future selection of differential tests the deduction and induction forms.

So, making the conclusion, the theoretical model of tests on the distinction the deduction form is like this:

\section{GIVEN:}

1)general sign;

2) multiple of particular sign;

3) logical attitude

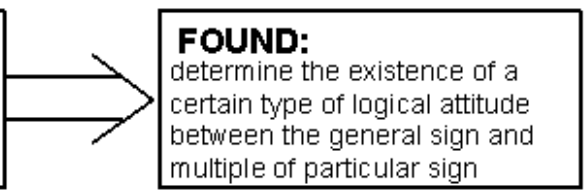

Fig. 5. The model of differential recognition tests on the distinction of orientation level ${ }^{24}$

The model of tests on the distinction the induction form is like this:

\begin{tabular}{|c|c|}
\hline $\begin{array}{l}\text { GIVEN: } \\
\text { 1) multiple of particular } \\
\text { sign; } \\
\text { 2)general sign; } \\
\text { 3) logical attitude }\end{array}$ & $\begin{array}{l}\text { FOUND: } \\
\text { determine the existence of a } \\
\text { certain type of logical attitude } \\
\text { between the general sign and } \\
\text { multiple of particular sign }\end{array}$ \\
\hline
\end{tabular}

Fig. 6. The model of differential recognition tests on the distinction of orientation level the induction form ${ }^{25}$

The model of tests on the distinction the induction and deduction forms is like this:

\begin{tabular}{|l|l|l|}
\hline GIVEN: & \multicolumn{1}{|l|}{$\begin{array}{l}\text { FOUND: } \\
\text { determine the existence of a } \\
\text { multiple of particular sign; } \\
\text { general sign; } \\
\text { logical attitude }\end{array}$} & $\begin{array}{l}\text { between the general sign and } \\
\text { multiple of particular sign }\end{array}$ \\
\cline { 2 - 3 }
\end{tabular}

Fig. 7. The model of differential recognition tests on the distinction of orientation level ${ }^{26}$

${ }^{24}$ Олійник Ю.С. Методика тестування знань зі електромагнітних перехідних процесів у майбутніх інженерів-електроенергетиків : автореф. дис. ... канд. пед. наук: 13.00.02. Харків. 2011. 20 с., p. 8.

25 Лазарєв М.І., Олійник Ю.С., Хоменко В.Г. Теоретичні та методичні засади тестування знань 3 електромагнітних перехідних процесів : монографія. Харків. 2012. 176 c., p. 46. 
Let's consider the particular example of differential test on distinction the deductive form with logical attitude between elements "numerouselement": "Let chose the answers which belong to transitional processes and are the most common:

a. Transition processes resulting from availability relay protection;

b. Transition processes resulting from availability disconnector;

c. Transition processes resulting from availability wrong acts of staff;

d. Transition processes caused by short circuits or repeating switching on and off the short chain;

e. Transition processes connected with switching on and off the electric consumer;

f. Transition processes resulting the quickly switching vacuum switch;

g. Transition processes resulting force extinguishment electromagnetic field of machines;

h. Unsynchronized switching the synchronous machines;

This example has the general notion - "transition processes", the particular notion - "transition processes resulting from availability relay protection" and "transition processes caused by short circuits or repeating switching on and off the short chain". The list of right answers is the components of sign "transition processes", so, it connects with each other by the logical attitude "numerous-element".

Let's consider the particular example of differential test on distinction the inductive form with logical attitude between elements "numerouselement": "Define to which kinds of short circuit included the two-phase short circuit to earth, one-phase short circuit and two-phase short circuit:

- symmetric short circuit;

- symmetric short circuit;

- mixed short circuit;

This example has the general notion - "asymmetric short circuit", the particular notion - "two-phase short circuit to earth, one-phase short circuit and two-phase short circuit".

So, it's connected between each other like "numerous-element".

Let's consider the kind of attitude of "reason-consequence" by which connected the general and particular notions in the differential test on distinction the inductive and deductive forms.

Let's consider the particular example of differential test on distinction the deduction form with kind of attitude between elements "reasonconsequence": "If current of short circuit calculates above $1 \mathrm{~kW}$ the needs take out account the next approval:

${ }^{26}$ Олійник Ю.С. Методика тестування знань зі електромагнітних перехідних процесів у майбутніх інженерів-електроенергетиків : автореф. дис. ... канд. пед. наук: 13.00.02. Харків. 2011. 20 с., р. 8. 
- Taking into account the active resistance of the elements;

- Failure to take into account the active resistance of the elements;

- Approximate load count.

According to V.P. Bespalko the last kind of test the first level is the tests for classification. These tests have the next features: the existence of numerous general notions the high level and the numerous the particular notions the low level.

The classification's purpose consists of the establishment the attitude between the numerous of the particular notion with the one general notion on the appropriate grounds the one classification; and the numerous particular notion with the other general notion on the appropriate grounds the other classification. The logical attitude between the elements might be "numerous-element", "reason-consequence" or "integer-part".

The model of classification tests the deduction form is like this:

\begin{tabular}{|c|c|}
\hline $\begin{array}{l}\text { GIVEN: } \\
\text { numerous of particular } \\
\text { notion; numerous of } \\
\text { general notion; } \\
\text { logic al attitude }\end{array}$ & $\begin{array}{l}\text { FOUND: } \\
\text { determine the existence of a } \\
\text { certain type of logical attitude } \\
\text { between the general notion and } \\
\text { numerous of particular notion }\end{array}$ \\
\hline
\end{tabular}

Fig. 8. The model of differential classification test orientation level the deduction form ${ }^{27}$

The model of classification tests the induction and deduction forms is like this:

\begin{tabular}{|l|l|l|}
\hline GIVEN: & $\begin{array}{l}\text { FOUND: } \\
\text { 1)numerous of particular } \\
\text { notion; }\end{array}$ \\
\cline { 2 - 2 } $\begin{array}{l}\text { 2) numerous of general } \\
\text { notion; } \\
\text { 3)logical attitude }\end{array}$ & $\begin{array}{l}\text { certain type of logical attitude } \\
\text { betw een the numerous of } \\
\text { general notion and numerous of } \\
\text { particular notion }\end{array}$ \\
\hline
\end{tabular}

Fig. 9. The model of the differential tests on the classification the oriental level the inductive form ${ }^{28}$

27 Лазарєв М.І., Олійник Ю.С., Хоменко В.Г. Теоретичні та методичні засади тестування знань 3 електромагнітних перехідних процесів : монографія. Харків. 2012. 176 c., p. 45.

28 Лазарєв М.І., Олійник Ю.С., Хоменко В.Г. Теоретичні та методичні засади тестування знань 3 електромагнітних перехідних процесів : монографія. Харків. 2012. 176 c., p. 48. 
Let's consider the example of differential tests of the classification the deduction form with logical attitude "numerous-element": "Define which the event belongs to reason of appears the short circuit and which is the consequence of short circuit:

- electrodynamic effect;

- sharp decreasing of voltage;

- direct lightning strike;

- overvoltage;

- system instability;

- thermal action;

- the bad care of electrical equipment;

- the danger for staff;

- the breaking of isolation the electrical equipment.

This example has the general notion the one classification - it's the reasons of short circuit, the general notion the other classification - it's the consequence, the particular notion of the one classification - electrodynamic effect; sharp decreasing of voltage; direct lightning strike; overvoltage; system instability; thermal action; the bad care of electrical equipment; the danger for staff; the breaking of isolation the electrical equipment.

The example of the classification test the induction form is like this: "Define in which phenomenon belongs to direct lightning strike; overvoltage; the bad care of electrical equipment; the breaking of isolation the electrical equipment, and in which - electrodynamic effect; sharp decreasing of voltage; system instability; thermal action; the danger for $\operatorname{staff}^{29}$ :

- reasons of short circuit;

- consequence of short circuit;

- symmetric short circuits;

- asymmetrical short circuits.

So, V.P. Bespalko's test's classification has a future development. Firstly, this development is in the detailing and differentiation the first's level tests, that is between in the first's level tests shows the deduction test (from general to particular notion) and induction (from particular to general). Secondly, as we mentioned, the combined tests with a several kind of logical attitude are developed.

According to V.P. Bespalko the next level is the conceptual-analytical level, which is the task solved by the known algorithm. The notions "given" and "found" connect with each other by the notion "algorithm" founding value ${ }^{30}$.

29 Олійник Ю.С. Теоретичне обгрунтування та розробка моделей тестів за рівнями засвоєння знань 3 електромагнітних перехідних процесів майбутніх інженерів-електроенергетиків. Гуманізація навчально-виховного процесу: зб. наук. пращь. Вип. LIV. 2011. Слов'янськ, с. 128-137., р. 17.

${ }^{30}$ Беспалько В.П. Слагаемые педагогической технологии. Москва, 1989. 192 с., р. 63. 
The purpose of this test found the value of the known parameter. The task presented by the given information, numerical value, formula, solution's algorithm.

The standard task must be consisted of the several given data and task to find the several value. The given task as usual has a scheme, numerical data of elements, formulas knowing earlier.

This level's task provides for the solution of the typical task by the known algorithm, in every which case the numerical data is changing, the algorithm doesn't change.

For instance, this scheme has a fixed set of elements and certain shortcircuit point.

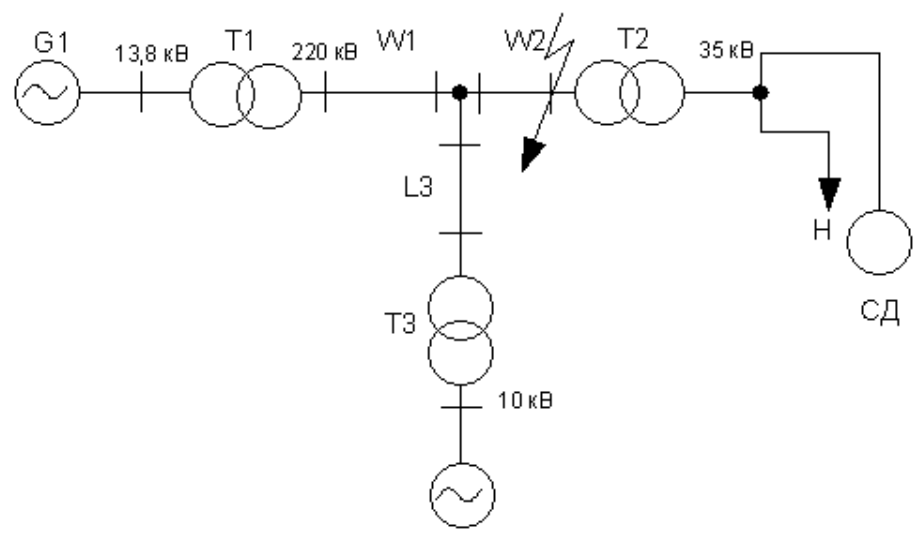

G2

Given: G1: $P_{H}=150 \mathrm{MVt}, x_{d}^{\prime \prime}=0,2, \cos \varphi=0,8 ; \mathrm{G} 2: P_{H}=100 \mathrm{MVt}$, $x_{d}^{\prime \prime}=0,125, \cos \varphi=0,8 ; \mathrm{T} 1: S_{H}=125$ MVA, $U_{K}=11 \% ; \mathrm{T} 2: S_{H}=63$ MVA, $U_{K}=10 \% \quad ;$ T3: $S_{H}=80$ MVA, $U_{K}=9,5 \% ; \quad S_{H}=35$ MVA, $x_{H}=0,35 ; \quad S_{\text {СД }}=15 \quad$ MVA $\quad x_{d}^{\prime}=0,2 ; \quad W_{1}=40 \mathrm{~km}, x_{0}=0,4 \mathrm{Om} / \mathrm{km}$; $W_{2}=60 \mathrm{~km}, x_{0}=0,4 \mathrm{Om} / \mathrm{km} ; W_{3}=50 \mathrm{~km}, x_{0}=0,4 \mathrm{Om} / \mathrm{km} ; K_{\text {уд. }}=1,65$.

Find the value of periodic component the short's circuit current in the time $t=0$.

The notion "given" in this example has a scheme, numerical parameters of scheme's elements and place of short circuit.

The notion "find" is defined the periodic component the short's circuit current in the time. If you find the necessary value, you need to define the algorithm of task's solution and necessary value calculates.

The model of tests the conceptual-analytical level is like this: 


\section{GIVEN:}

variable number data

(scheme, numerical

values of elements, kind

(place) of short circuit, formulas.

\section{FOUND:}

1) algorithm of solution;

2) define the particular value by this algorithm

\section{Fig. 10. The model of conceptual-analytical level ${ }^{31}$}

Let's consider the testing on the productive-synthetic level. According to Bespalko's theory the third level has the next facts: "If the task has a purpose, but the situation isn't clear and the pupil must add the situation and use the action, which he gives earlier, it's the reproductive action heuristic type",32.

The baseline data, as usual, have some scheme, some scheme's numerical values and additional conditionals by which this task has the name non-standard.

The test this level includes for the existence of an atypical task, which solution is by the algorithm creating in the process of solution.

For instance, we have the scheme.

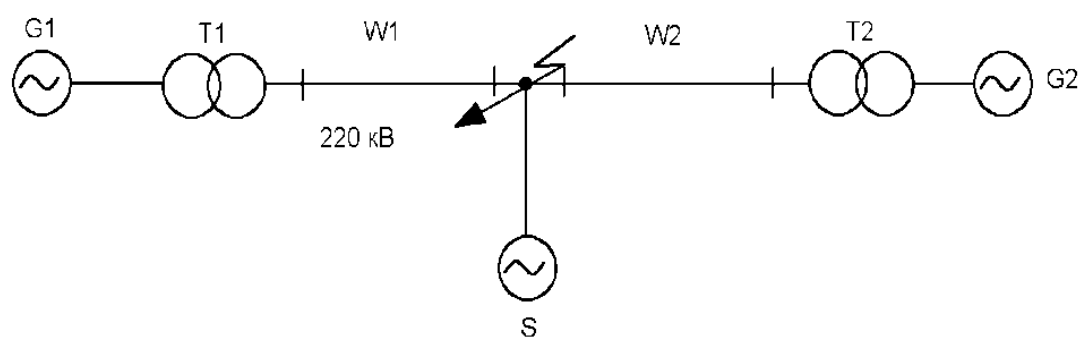

G1: $P_{H 1}=40 \mathrm{MVt}, x_{d}^{\prime \prime}=0,15, \cos \varphi=0,8 ; \mathrm{T} 1: S_{H 1}=63$ MVA, $U_{K}=11 \% ; W_{1}=95 \mathrm{~km}, x_{0}=0,4 \mathrm{Om} / \mathrm{km} ; W_{1}=70 \mathrm{~km}, x_{0}=0,4 \mathrm{Om} / \mathrm{km}$; System: $I_{K .3}=12 \kappa A$; T2: $S_{H 2}=125$ MVA, $U_{K}=11 \%$; T3: $S_{H 3}=60$ MVA, $U_{K}=10,5 \% ; \mathrm{G} 2: P_{H 2}=160 \mathrm{MVt}, x_{d}^{\prime \prime}=0,213, \cos \varphi=0,85$; $K_{\text {уд. }}=1,65$.

The periodic component in the time $\left.t=0\left(I_{n 0}\right)\right)$ and strike current $-i_{y \partial}$. need to find.

31 Олійник Ю.С. Методика тестування знань зі електромагнітних перехідних процесів у майбутніх інженерів-електроенергетиків : автореф. дис. ... канд. пед. наук : 13.00.02. Харків. 2011. 20 с., р. 10.

32 Беспалько В.П. Слагаемые педагогической технологии. Москва, 1989. 192 c., p. 63. 
The main difference the conceptual-analytical level's tasks from the productive-synthetic level is in the algorithm's solution difference. When we solution the typical task, we use the particular algorithm. When we solution the non-typical task, this algorithm is changing every time and depending on baseline data ${ }^{33}$.

The model of productive-synthetic level is like this:

\begin{tabular}{|l|l|l|}
\hline GIVEN: & \multicolumn{1}{|l|}{\begin{tabular}{l} 
FOUND: \\
1) new algorithm for \\
variable number data \\
(scheme, numerical \\
values of elements, kind \\
\cline { 3 - 3 } (place) of short circuit, \\
formulas.
\end{tabular}} & $\begin{array}{l}\text { students which is based } \\
\text { on the known algorithm; } \\
\text { 2) define the particular } \\
\text { value by this algorithm }\end{array}$ \\
\hline
\end{tabular}

Fig. 11. The model of productive-synthetic level ${ }^{34}$

\section{CONCLUSIONS}

This article is dedicated of problem the increasing of educational's quality the future specialist in the energy. This problem's solution is realized by the development and justification the educational's testing methodic the discipline "Electromagnetic transition processes".

According to the Bespalko's theory the tasks have a question the orientation level deduction and induction form. This level consists from three kinds of tasks:

- The model of differential recognition tests the orientation level the deductive form and induction form;

- The model of differential recognition tests on the distinction of orientation level the deductive form and induction form;

- The model of differential classification test orientation level the deductive form and induction form;

In the article there are examples of tasks on each kind of orientation level the deduction and induction forms.

The next level, which we considered, is the conceptual-analytical level's example is the standard task which the student solves the task by the known algorithm.

The last level, which we are considering, was the productive-synthetic level. The task of this level is the non-standard task. This kind test doesn't solve by the standard and known algorithm. Solving this task student have to

${ }^{33}$ Беспалько В.П. Слагаемые педагогической технологии. Москва, 1989. 192 с., p. 63-64.

34 Олійник Ю.С. Методика тестування знань зі електромагнітних перехідних процесів у майбутніх інженерів-електроенергетиків : автореф. дис. ... канд. пед. наук : 13.00.02. Харків. 2011. 20 с., p. 10. 
find and use the algorithm which is particular only for these scheme and baseline data.

Using all this system for the education of students has an opportunity for increasing the quality of educational the future energy engineers.

\section{SUMMARY}

Nowadays labor market needs to employee who have a high qualification of power engineering. The article dedicated the problem of technical education in Ukraine. The quality of education depends on control system the knowledge which the students had given during the educational process. The author considered the one of the most important disciplines which called "Electromagnetic transitions" for the education of future power engineers. The most successful control of this knowledge is the test of different levels and different kinds. It helps to repeat and secure educational material on the particular topic. The article has a several particular examples of various levels and types for the different topic of discipline. Students who have a testing tasks on different levels show the increasing of learning indicators.

\section{REFERENCES}

1. Беспалько В.П. Слагаемые педагогической технологии. Москва, 1989. $192 \mathrm{c}$.

2. Булах I.С., М.Р. Мруга Створюємо якісний тест : навчальний посібник. Київ, 2006. 160 с.

3. Гончаренко С.У., Ничкало Н.Г., Петренко В.Л. Державні стандарти професійної освіти: теорія і методика. Хмельницький, 2002. $334 \mathrm{c}$.

4. Самылкина Н.Н. Современные средства оценивания результатов обучения. Москва, 2007. 172 с.

5. Олійник Ю.С. Методика тестування знань зі електромагнітних перехідних процесів у майбутніх інженерів-електроенергетиків : автореф. дис. ... канд. пед. наук : 13.00.02. Харків. 2011. 20 с.

6. Норман Е. Гронлунд Оцінювання студентської успішності. Київ, 2005. $312 \mathrm{c}$.

7. Олійник Ю.С. Теоретичне обгрунтування та розробка моделей тестів за рівнями засвоєння знань 3 електромагнітних перехідних процесів майбутніх інженерів-електроенергетиків. Гуманізація навчально-виховного процесу: зб. наук. пращьь. Вип. LIV. 2011. Слов'янськ. С. 128-137.

8. Пантєлєєва І.В., Олійник Ю.С. Перехідні процеси в системах електропостачання. Харків, 2011. 126 с.

9. Хоменко В.Г., Олійник Ю.С. Система тестування 3 дисципліни «Електромагнітні перехідні процеси». Харків, 2010. 104 с.

10. Ярощук Л. Основи педагогічних вимірювань та моніторингу якості освіти: навч. посіб. Луцьк. 2010. 308 с. 
11. Лазарєв М.І., Олійник Ю.С., Хоменко В.Г. Теоретичні та методичні засади тестування знань 3 електромагнітних перехідних процесів : монографія. Харків, 2012. 176 с.

\section{Information about the author:}

Oliinyk Yu. S.,

$\mathrm{Ph} . \mathrm{D}$. in Pedagogic Science, Associate Professor at the Department of Physics,

Electrical Engineering and Power Engineering Ukrainian Engineering Pedagogics Academy 16, Universitetska str., Kharkov, 61000, Ukraine 